\title{
Development and evaluation of a recombinase polymerase amplification assay for rapid detection of strawberry red stele pathogen
}

\author{
Mustafa Ahmad Munawar ${ }^{1 *}$ (D, Anna Toljamo ${ }^{1}$, Frank Martin², Elina Oksanen ${ }^{1}$ and Harri Kokko ${ }^{1}$
}

\begin{abstract}
Phytophthora fragariae causes drastic damage in strawberry crops. P. fragariae infects strawberry roots and causes red stele root rot. Although $P$. fragariae is a quarantine organism, its spread in Finland continues as more and more fields contract the disease. The spread can be halted through developing rapid and reliable detection assays. We have developed a rapid recombinase polymerase amplification (RPA) assay for $P$. fragariae targeting the Phytophthora mitochondrial DNA intergenic atp9-nad9 marker. The assay is DNA-extraction free and capable of detecting as low as $10 \mathrm{fg}$ of $P$. fragariae genomic DNA. We found the assay reliable for diagnosing field plants when samples are adequately collected. We also applied the RPA assay to the detection of the pathogen in the soil through coupling the assay with baiting with the host plant. The results suggest that if only a small number of samples are analysed, the baiting results will not be reliable.
\end{abstract}

Keywords: Phytophthora fragariae, Red stele, Recombinase polymerase amplification, Crude maceration, Baiting, Indicator plants

\section{Background}

Phytophthora fragariae is a quarantine organism (A2 list of EPPO) and causes red stele root rot of strawberry. This disease is common in regions with cool and moist climates, with damage more extensive in heavy saturated clay soils and during early or late summer. The pathogen first destroys fine roots and later progresses upwards in the stele of larger roots. Plants wilting usually first appears in low or poorly drained areas of fields and the affected area progressively widens over time. When plants with early wilting symptoms are dug out, their major roots have less lateral roots and present a 'rat-tail appearance'. Dissecting major roots upwards displays abnormal reddish colour in internal cores known as 'red

\footnotetext{
* Correspondence: mustafm@student.uef.fi

'Department of Environmental and Biological Sciences, University of Eastern Finland, 70211 Kuopio, Finland

Full list of author information is available at the end of the article
}

stele' and considered as a typical diagnostic feature of the disease. The disease has drastic nature and causes wilting, stunted growth, less or no strawberries and few stolons. Moreover, the pathogen can persist at least ten years in infested soils through its survival form of oospores (Maas, 1998; Ellis, 2008; Newton et al. 2010).

The disease has badly damaged strawberry crops in North America, Switzerland, Germany, France and Sweden (Maas 1998). P. fragariae was not present in Finland according to the EPPO/ CABI, 1997. The absence of the pathogen was also confirmed by the countrywide survey for red-stele disease conducted on strawberry roots collected in 1995 (Pohto 1999). However, in 2012 EVIRA (Finnish Food Safety Authority) surprisingly detected $P$. fragariae for the first time among 55 of the strawberry plantations collected from outdoor horticultural production in different regions of Finland (EVIRA 2013). In North Savo region of Finland, we have observed crop

(c) The Author(s). 2020 Open Access This article is licensed under a Creative Commons Attribution 4.0 International License, which permits use, sharing, adaptation, distribution and reproduction in any medium or format, as long as you give appropriate credit to the original author(s) and the source, provide a link to the Creative Commons licence, and indicate if changes were made. The images or other third party material in this article are included in the article's Creative Commons licence, unless indicated otherwise in a credit line to the material. If material is not included in the article's Creative Commons licence and your intended use is not permitted by statutory regulation or exceeds the permitted use, you will need to obtain permission directly from the copyright holder. To view a copy of this licence, visit http://creativecommons.org/licenses/by/4.0/. 
damages (loss of plants) of up to $90 \%$, while we have diagnosed 17 fields with red stele among the 42 problematic fields investigated in summer 2017 and 2018. Strawberry crop has a unique importance in Finland. Out of the total 19,131 ha open area cultivated during 2018 in Finland, 4160 ha area produced strawberry with a total yield over 15 million kg (Niemi and Väre 2019).

Common techniques employed for Phytophthora diagnosis include symptom observation, microscopy, baiting, immunological assays, and polymerase chain reaction (PCR) (Martin et al. 2012). Duncan (1976) employed susceptible alpine strawberry as bait to quantify the pathogen in infested soils. The bait plants Fragaria vesca clone VS1, and Fragaria vesca var. alpina (Baron Solemacher) were planted with different dilutions of soil and kept at $15^{\circ} \mathrm{C}$ for 5 weeks. After 5 weeks, bait plants were examined for red steles and oospore presence. In another article, Duncan (1980) presented a root-tip bait method for the detection of red stele disease in stock plants. In this method, root tips were collected from stock plants and mixed with compost. Then the tipscompost mixtures were added to pots and planted with bait plants Fragaria vesca var. alpina (Baron Solemacher). Plant pots were watered every $6 \mathrm{~h}$ through mist irrigation, and the temperature was maintained at $15^{\circ} \mathrm{C}$. After 5 weeks, bait plants were examined for red steles and oospore presence. The root-tip baiting was reported sufficiently sensitive with capability to detect even one infected plant among 99 healthy ones.

For immunological diagnosis, antisera raised against mycelia of Phytophthora fragariae showed crossreactivity with other Phytophthora and Pythium species (Amouzou-Alladaye et al. 1988; Werres 1988; Mohan 1989). In contrast, PCR development has been successful over time. The foremost PCR assays developed for the detection of $P$. fragariae utilized the multicopy internal transcribed spacer (ITS) region. Stammler and Seemüller (1993) developed a PCR assay from the ITS region of the rDNA for the detection of Phytophthora rubi and found the assay equally specific for $P$. fragariae. Later Bonants et al. (1997) found the assay less sensitive and cross-reacting with Phytophthora citrophthora, Phytophthora nicotianae A1 and Phytophthora capsici. Using the ITS region, Bonants et al. (1997) further developed a nested PCR assay, and improved specificity and sensitivity of $P$. fragariae detection. The nested PCR was able to detect the pathogen in symptomless plants with a sensitivity reported down to twenty zoospores. The nested PCR was also coupled with ELISA (enzymelinked immunosorbent assay), and for the purpose, a capture probe was designed according to an ITS 1 location with maximum basepair difference from other Phytophthora species. The PCR-ELISA design resulted in superior specificity. In a separate study, Bonants et al.
(2004) coupled the nested PCR assay with bait test and shortened the baiting time up to 14 days. The study also compared the sensitivity of different PCR formats for the detection of P. fragariae DNA. The PCR formats of gel electrophoresis, PCR-ELISA, TaqMan, and Molecular Beacon were reported equally sensitive, all detecting as low as 100 ag $P$. fragariae DNA through nested PCR. In contrast, the DIAPOPS (detection of immobilized amplified product in a one-phase system) format was reported less sensitive with detection limit as low as $10 \mathrm{fg} P$. fragariae DNA through nested PCR.

Besides development of Phytophthora species-level PCR assays, the ITS region has also been utilized to develop Phytophthora genus-specific PCR assays and those assays were coupled with restriction enzymes or sequencing to identify different Phytophthora species including P. fragariae (Cooke and Duncan 1997; Ristaino et al. 1998; Camele et al. 2005; Drenth et al. 2006). Single copy genes containing introns have also been employed for $P$. fragariae-specific PCR assays. Ioos et al. (2006) developed single-round PCR assays from $R A S$-like and TRP1 genes with sensitivity down to $100 \mathrm{fg}$. Recently, a multicopy mitochondrial marker, the spacer between the atp9-nad9 genes, with an appropriate level of variation among Phytophthora species was used to develop species-specific diagnostic assays. The atp9-nad9 is a unique marker of the genus Phytophthora and it is a highly conserved gene order present in almost all the Phytophthora species but absent in the related genus Pythium, Eumycotan fungi and plants (Bilodeau et al. 2014; Miles et al. 2015; Miles et al. 2017). With this locus several Phytophthora species-specific assays have been developed, including assays for $P$. fragariae: TaqMan qPCR assays (Bilodeau et al. 2014; Miles et al. 2017; Rojas et al. 2017; Hao et al. 2018; Munawar et al. 2020), SYBR Green PCR assays (Munawar et al. 2020), and recombinase polymerase amplification (RPA) assays (Miles et al. 2015; Rojas et al. 2017; Munawar et al. 2019).

Certified commercial plant stock was reported to have been infected with red stele (Duncan 1980). In 2017, we have also found red steles in one of the certified nursery plant boxes imported from another EU member country to the North Karelia region of Finland. P. fragariae infection also has a cryptic nature and can be distributed via asymptomatic exported plants. Besides the cryptic nature of the pathogen, disease symptoms may also disappear during warm summer weather (McGrew 1889). Moreover, in the case of extensive field damage, the leftover plants do not always present red steles. For these reasons, a rapid, sensitive, on-site and reliable assay such as RPA is of the utmost importance. In this study we are presenting development of an RPA assay for detection of $P$. fragariae through atp9-nad9 marker, following our previous assay design (Munawar et al. 2019). 


\section{Results}

Isolation of $P$. fragariae and sequencing of atp9-nad9 marker

For isolation of $P$. fragariae from infected field plants, we collected red cores, disinfected them with the traditional isolation reagent 'Teepol L Detergent' or routine 70\% ethanol, and plated them on Phytophthora selective agar. Images of an infected plant, rat-tails, and red cores are presented in Fig. 1. We performed isolation trials for 17 red stele-infected fields but succeeded with only three fields. We also compared the traditional Teepol L Detergent disinfection method with the routine $70 \%$ ethanol disinfection during isolation trials from three of the infected fields. We found no difference between the two methods in restriction of contaminant growth on the Phytophthora selective agar. Moreover, we sequenced the three of our P. fragariae isolates (MRV1, VTJ1 and KRT1), the SCRP245 fvf7 P. fragariae isolate, and five $P$. fragariae infected plants, all originating from different fields, and observed unvaried atp-nad9 sequence identical to the GenBank accession numbers JF771842, JF771843, or JF771844.

\section{Optimum RPA assay}

Miles et al. (2015) provided partial atp9-nad9 sequences of more than one hundred Phytophthora species to support further development of Phytophthora assays. We

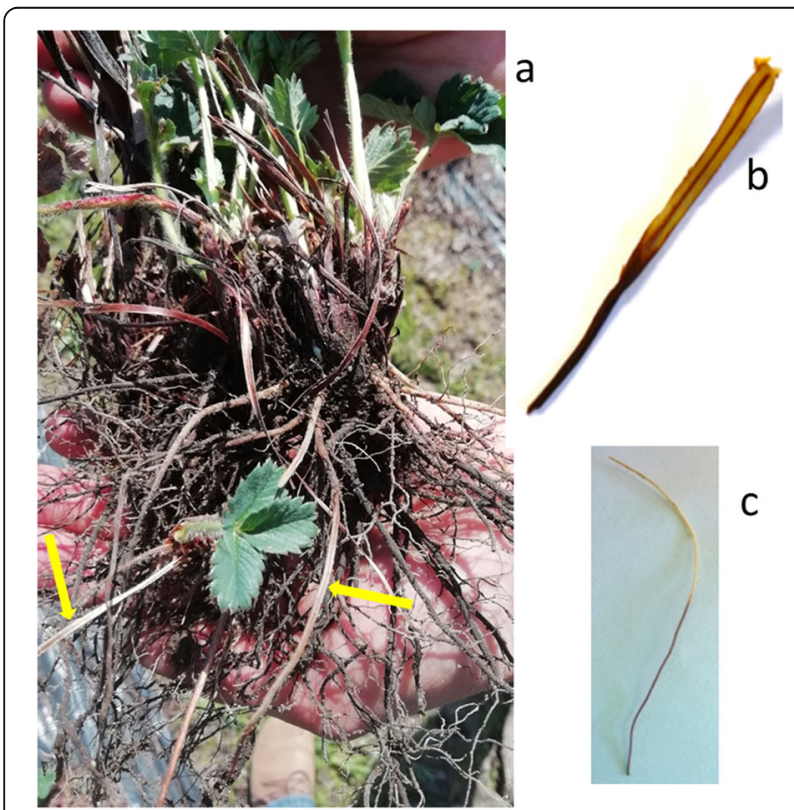

Fig. 1 Typical symptoms of red stele disease of strawberry. a A stunted plant held by hands. The plant is suffering from red stele disease and the yellow arrows are pointing to the dissected rat-tails displaying red cores. $\mathbf{b}$ A detached dissected rat-tail root displaying red core. c A fully pealed root core prior to plating on Phytophthora selective agar. The lower part of the core has turned red due to red stele disease aligned those sequences with Geneious 8.1.9 (Geneious, New Zealand) and recognized the partial atp 9 gene sequence, intergenic spacer, and partial nad9 gene sequences. We have presented alignment of the atp9-nad9 sequences, keeping one isolate per Phytophthora species (Additional file 1: Figure S1). Subsequently, we designed an RPA assay by picking forward RPA primers from the genus-conserved region of the atp 9 gene, and reverse RPA primers and an overlapping reverse probe (TwistAmp exo probe) from the intergenic spacer between the atp 9 and nad 9 genes. The positions of each primer and probe for the optimized RPA assay are presented in Fig. 2.

The RPA assay was optimum with the forward primer 'Phy_Gen_F3' at a concentration of $600 \mathrm{nM}(3 \mu \mathrm{L}$ of $10 \mu \mathrm{M})$, reverse primer 'Phy_Frag_R29' at a concentration of $260 \mathrm{nM}(1.3 \mu \mathrm{L}$ of $10 \mu \mathrm{M})$, and the probe 'Phy_ Frag_RevP3' at a concentration of $100 \mathrm{nM}(0.5 \mu \mathrm{L}$ of $10 \mu \mathrm{M})$. Rest of the components were kept as per manufacturer's recommendations. Template or macerated sample volume was kept at $1 \mu \mathrm{L}$. Primer and probe sequences are presented in Table 1.

\section{Sensitivity and specificity of RPA assay}

We evaluated sensitivity of the RPA assay through amplifying 1/10 dilution of $P$. fragariae (MRV1 isolate) genomic DNA ranging from $1 \mathrm{ng} / \mu \mathrm{L}$ to $1 \mathrm{fg} / \mu \mathrm{L}$. We prepared dilutions of genomic DNA extracted from dried hyphae of $P$. fragariae and quantified with a Qubit 2.0 Fluorometer, utilizing Qubit dsDNA HS Assay Kit (Thermo Fisher Scientific). We found the RPA assay could consistently detect down to $10 \mathrm{fg}$ of $P$. fragariae genomic DNA (five repeats). Amplification curves are presented in Fig. 3. We repeated the amplification of DNA dilutions after spiking individual RPA reaction with $1 \mu \mathrm{L}$ of healthy rootlet macerate. Spiking with healthy rootlets macerate slightly raised baseline fluorescence signal in all tubes and only lessened steepness of $10 \mathrm{fg}$ curve (data not shown). We also compared the sensitivity of the RPA assay in parallel with the $P$. fragariae-specific SYBR Green and TaqMan PCR assays described by Munawar et al. (2020) and Bilodeau et al. (2014). The result showed that the $P$. fragariae-specific TaqMan and SYBR PCR assays are more sensitive with a detection limit down to $1 \mathrm{fg}$ of $P$. fragariae genomic DNA (four replicates for both PCR assays). The RPA assay amplified all of the four $P$. fragariae isolates and presented no amplification with 50-100 pg DNA of Phytophthora cactorum, Phytophthora taxon raspberry, Phytophthora megasperma, Phytophthora rosacearum, Phytophthora ramorum, Phytophthora plurivora, Phytophthora pini, Phytophthora cambivora, Phytophthora cinnamomi, Pythium sylvaticum, Botrytis cinerea, Colletotrichum acutatum, Mucor hiemalis, Fusarium avenaceum, and Fusarium proliferatum. Details of the isolates utilized 


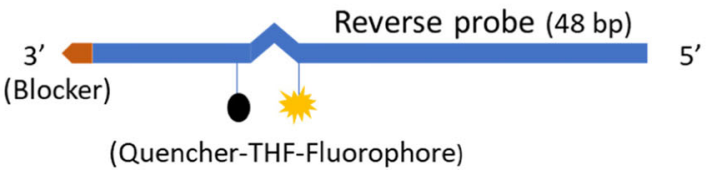

Fig. 2 Location of primers and probe in the RPA assay

in sensitivity and specificity analyses are provided in Table 2.

\section{Maceration buffer}

Miles et al. (2015) tested different commercial and homemade buffers for their suitability for maceration of plant tissues aimed at RPA, and found GEB 2 (Agdia Inc. Unites States) and standard ELISA grinding buffer suitable for the purpose. We further investigated if all components of the homemade standard ELISA grinding buffer are crucial. We prepared a standard ELISA grinding buffer as $1 \times$ phosphate-buffered saline buffer supplemented with $2 \mathrm{~g}$ of bovine serum albumin (BSA), $20 \mathrm{~g}$ of PVP-40, and $0.5 \mathrm{~mL}$ of Tween 20 per litre buffer. We also prepared three modified ELISA grinding buffers, each missing one of the crucial components: BSA-free, PVP-free and Tween-free ELISA grinding buffers. All buffers were prepared without $\mathrm{pH}$ adjustment. We collected fine rootlets from naturally infected plants, and pooled, chopped, divided them equally into four $2 \mathrm{~mL}$ round-bottom Eppendorf tubes and weighted to prepare 1:10 (w/v) macerates. We macerated three samples with either BSA-free, PVP-free, or Tween-free ELISA grinding buffer and the fourth sample with a standard ELISA grinding buffer. After maceration, we tested supernatants from the four tubes with the RPA assay. We surprisingly found that the three rootlet samples macerated in BSA-free, PVP-free and Tween-free ELISA grinding buffers, and the fourth rootlet sample macerated in standard ELISA grinding buffer (full components) all gave equal amplification curves. We repeated the experiment and included a fifth tube in which rootlets were macerated only in autoclaved distilled water. All the five tubes had equal amplification curves with onset of amplifications between 5.0 and $5.5 \mathrm{~min}$.

\section{Field validation}

In the field validation by Munawar et al. (2020), 22 fine rootlet samples were collected or received from different problematic fields of North Savo region of Finland, crudely macerated in water for doing some RPA assay and also for extraction of DNA for further validation. The DNA samples were analyzed with $P$. fragariae- and P. cactorum-specific PCR assays, and a Phytophthora genus-specific PCR assay aimed for Sanger sequencing. The validation revealed that among the 22 rootlet samples, nine contained $P$. fragariae, one was co-infected with both $P$. fragariae and $P$. cactorum, and four contained $P$. cactorum. We also analyzed the rootlet macerates prepared by Munawar et al. (2020) in parallel with the $P$. fragariae-specific RPA assay of this study and compared the results. The $P$. fragariae-specific RPA assay of this study gave identical results with the ten rootlet samples containing $P$. fragariae. We also matched the results with plant symptoms and found nine out of the ten positive plants had typical red steles. Detailed results of the field validation are presented in Table 3. RPA results were recorded as time (minutes) of onset of amplification while PCR results are presented as $\mathrm{Ct}$ (cycle threshold).

Table 1 Sequences of the optimal primers and probe for the RPA assay

\begin{tabular}{lll}
\hline Primer/ probe & Name & Sequence (5'-3') \\
\hline Forward primer & Phy_Gen_F3 & TGATGGCTTTCTTAATTTATTTGCTTTTTA \\
Reverse Primer & Phy_Frag_R29 & TGTTGAAAAGAGCTAATTACGTATTAAATAT \\
TwistAmp exo probe & Phy_Frag_RevP3 & AATTACGTATTAAATATACATATATATC-T(ROX)-A-(dSpacer)-T(BHQ2)-ACGAGATTAATATAAT[3'-C3SPACER] \\
\hline
\end{tabular}




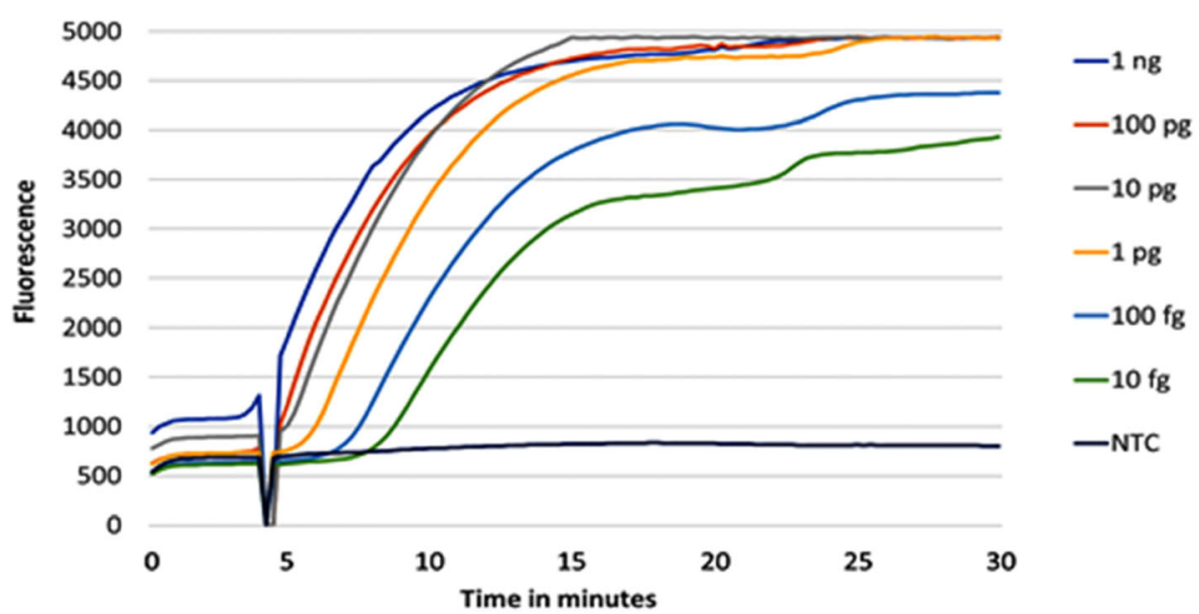

Fig. 3 Amplification curves of RPA assay for concentrations ranging from 1 ng to $10 \mathrm{fg}$ purified genomic DNA of $P$. fragariae

\section{Soil testing}

To evaluate combination of baiting and the RPA assay for testing soil contamination with $P$. fragariae, we employed three contaminated fields located in North Savo region of Finland and labelled them as A, B and C field. Similarly, we adopted two methods for baiting in the evaluation. In the first method, indicator plants Fragaria vesca var. alpina (Baron Solemacher), grown from seeds and approximately two months old, were planted in fields A and B for five weeks. The field A was actively suffering from red stele and at a low site, strawberry plants were progressively dying. We planted five indicator plants at the low site. The field B was cultivated with green peas, but it had a history of red stele infection a few years ago. We planted 10 indicator plants randomly across the field. After five weeks, we removed the indicator plants from fields A and B, observed symptoms and tested them with the RPA assay. We found all the five indicator plants from the field A were positive with the RPA assay while only one of them had typical symptom of red steles. Regarding the 10 indicator plants collected from the field $B$, none of them had red steles, while only one turned positive with the RPA assay.

In the second method of baiting, we utilized baiting units and soil samples from field C. Strawberry field C was destroyed by red stele disease in 2016 and 2017. In summer 2017, the farmer cultivated hemp on half of the field and green peas on the other half. The field $\mathrm{C}$ has an inclination, but no particular low or poorly drained site. In spring 2018, we collected eight soil samples from lower and hemp side, and eight soil samples from lower and pea side. We transferred the 16 soil samples into baiting units and also set up two negative and two positive control baiting units. Positive units were added with soil containing artificially infected strawberry roots (from another study), while in negative units, containers were solely filled with distilled water. On day 7, 10, 14, 21, 35, and 49 we removed three indicator plants or their roots hanging in the water from each baiting unit, pooled them and tested with the RPA assay. On day 7, two of the eight baiting units containing soil from hemp side of the field were positive, while none of the units representing the pea side were positive with the $P$. fragariae RPA assay. Positive controls were also positive for $P$. fragariae on day 7. On the 10th day, positive units among the hemp-related baiting units remained at two, while one unit was positive among the eight baiting units containing soil from pea side of the field. On day 14 results were the same as day 10 . On the 21st day, the RPA results remain unchanged for soil from the hemp cropped field, while another unit was positive (total two) among the eight pea-related baiting units. RPA testing on the 35th day ( 5 weeks) revealed a total of three positive among the eight units containing soil from the hemp side of the contaminated field, while positive units among the baiting units added with soil from pea side of the field remained two. On day 49 results were the same as day 35 . The rootlets from negative control units remained negative till day 49 . We also noticed darkening of the roots in all positive baiting units after around a week of RPA positivity. The results of soil testing through baiting units are summarized in Table 4.

\section{Discussion}

Designing a species-specific PCR detection assay requires a marker with high discriminatory power, with a superior sensitivity achieved through the use of a multicopy marker. The ITS region is a high-copy locus widely used for species identification, but it has limited resolution power to discriminate among Phytophthora species. Recently, Phytophthora species-specific RPA assays targeting the single copy gene Ypt1 have been developed 
Table 2 Isolates utilized in sensitivity and specificity analyses and their origins

\begin{tabular}{|c|c|c|c|c|}
\hline Species & $\begin{array}{l}\text { Isolate } \\
\text { number }\end{array}$ & Host & Source/Origin & $\begin{array}{l}\text { Result of } \\
\text { specificity } \\
\text { analysis }\end{array}$ \\
\hline $\begin{array}{l}\text { Phytophthora } \\
\text { fragariae }\end{array}$ & MRV1 & Fragaria ananassa & $\begin{array}{l}\text { Isolated from North Savo region of Finland by the University of } \\
\text { Eastern Finland }\end{array}$ & $\begin{array}{l}\text { Amplification } \\
\text { onset at } \sim 5 \\
\text { min }\end{array}$ \\
\hline $\begin{array}{l}\text { Phytophthora } \\
\text { fragariae }\end{array}$ & VTJ1 & Fragaria ananassa & $\begin{array}{l}\text { Isolated from North Savo region of Finland by the University of } \\
\text { Eastern Finland }\end{array}$ & $\begin{array}{l}\text { Amplification } \\
\text { onset at } \sim 5 \\
\text { min }\end{array}$ \\
\hline $\begin{array}{l}\text { Phytophthora } \\
\text { fragariae }\end{array}$ & KRT1 & Fragaria ananassa & $\begin{array}{l}\text { Isolated from North Savo region of Finland by the University of } \\
\text { Eastern Finland }\end{array}$ & $\begin{array}{l}\text { Amplification } \\
\text { onset at } \sim 5 \\
\text { min }\end{array}$ \\
\hline $\begin{array}{l}\text { Phytophthora } \\
\text { fragariae }\end{array}$ & $\begin{array}{l}\text { SCRP245 } \\
\text { fvf7 }\end{array}$ & Fragaria ananassa & Most probably isolated from United Kingdom & $\begin{array}{l}\text { Amplification } \\
\text { onset at } \sim 5 \\
\text { min }\end{array}$ \\
\hline $\begin{array}{l}\text { Phytophthora } \\
\text { cactorum }\end{array}$ & PO245 & Fragaria ananassa & $\begin{array}{l}\text { Isolated from Poland and donated by Grażyna Szkuta from } \\
\text { Państwowa Inspekcja Ochrony Roślin i Nasiennictwa }\end{array}$ & $\begin{array}{l}\text { No } \\
\text { amplification }\end{array}$ \\
\hline $\begin{array}{l}\text { Phytophthora } \\
\text { taxon raspberny }\end{array}$ & GE5 & $\begin{array}{l}\text { Unknown (species also confirmed } \\
\text { through atp9-nad9 sequencing) }\end{array}$ & Unknown origin & $\begin{array}{l}\text { No } \\
\text { amplification }\end{array}$ \\
\hline $\begin{array}{l}\text { Phytophthora } \\
\text { megasperma }\end{array}$ & GE9 & $\begin{array}{l}\text { Unknown (species also confirmed } \\
\text { through atp9-nad9 sequencing) }\end{array}$ & Unknown origin & $\begin{array}{l}\text { No } \\
\text { amplification }\end{array}$ \\
\hline $\begin{array}{l}\text { Phytophthora } \\
\text { rosacearum }\end{array}$ & SO18 & $\begin{array}{l}\text { Unknown (species also confirmed } \\
\text { through atp9-nad9 sequencing) }\end{array}$ & Unknown origin & $\begin{array}{l}\text { No } \\
\text { amplification }\end{array}$ \\
\hline $\begin{array}{l}\text { Phytophthora } \\
\text { ramorum }\end{array}$ & $\mathrm{Ph} 426$ & $\begin{array}{l}\text { Rhododendron catawbiense } \\
\text { 'Grandiflorum' }\end{array}$ & $\begin{array}{l}\text { Isolated from Finland and donated by Anna Poimala from the } \\
\text { Natural Resources Institute Finland (Luke) }\end{array}$ & $\begin{array}{l}\text { No } \\
\text { amplification }\end{array}$ \\
\hline $\begin{array}{l}\text { Phytophthora } \\
\text { plurivora }\end{array}$ & Ph441 & Rhododendron 'Marketta' & $\begin{array}{l}\text { Isolated from Finland and donated by Anna Poimala from the } \\
\text { Natural Resources Institute Finland (Luke) }\end{array}$ & $\begin{array}{l}\text { No } \\
\text { amplification }\end{array}$ \\
\hline $\begin{array}{l}\text { Phytophthora } \\
\text { pini }\end{array}$ & $\mathrm{Ph} 443$ & Rhododendron 'Capistrano' & $\begin{array}{l}\text { Isolated from Finland and donated by Anna Poimala from the } \\
\text { Natural Resources Institute Finland (Luke) }\end{array}$ & $\begin{array}{l}\text { No } \\
\text { amplification }\end{array}$ \\
\hline $\begin{array}{l}\text { Phytophthora } \\
\text { cambivora }\end{array}$ & $\begin{array}{l}\text { BBA 21/ } \\
95-\mathrm{K} \|\end{array}$ & $\begin{array}{l}\text { Chamaecyparis lawsoniana } \\
\text { 'Columnaris' }\end{array}$ & $\begin{array}{l}\text { Isolated from Germany and donated by Sabine Werres from Julius } \\
\text { Kühn-Institut (JKI) }\end{array}$ & $\begin{array}{l}\text { No } \\
\text { amplification }\end{array}$ \\
\hline $\begin{array}{l}\text { Phytophthora } \\
\text { cinnamomi }\end{array}$ & BBA62660 & Rhododendron sp. & $\begin{array}{l}\text { Isolated from Germany and donated by Sabine Werres from Julius } \\
\text { Kühn-Institut (JKI) }\end{array}$ & $\begin{array}{l}\text { No } \\
\text { amplification }\end{array}$ \\
\hline $\begin{array}{l}\text { Pythium } \\
\text { sylvaticum }\end{array}$ & ISO-VTJC & Fragaria ananassa & $\begin{array}{l}\text { Isolated from North Savo region of Finland by the University of } \\
\text { Eastern Finland }\end{array}$ & $\begin{array}{l}\text { No } \\
\text { amplification }\end{array}$ \\
\hline Botrytis cinerea & ISO-57C & Fragaria ananassa & $\begin{array}{l}\text { Isolated from North Savo region of Finland by the University of } \\
\text { Eastern Finland }\end{array}$ & $\begin{array}{l}\text { No } \\
\text { amplification }\end{array}$ \\
\hline $\begin{array}{l}\text { Colletotrichum } \\
\text { acutatum }\end{array}$ & PCF753 & Fragaria ananassa & $\begin{array}{l}\text { Isolated from Belgium and DNA donated by Jane Debode from } \\
\text { the Institute for Agricultural, Fisheries and Food Research (ILVO) }\end{array}$ & $\begin{array}{l}\text { No } \\
\text { amplification }\end{array}$ \\
\hline Mucor hiemalis & $\begin{array}{l}\text { ISO-125- } \\
\text { MKR }\end{array}$ & Fragaria ananassa & $\begin{array}{l}\text { Isolated from North Savo region of Finland by the University of } \\
\text { Eastern Finland }\end{array}$ & $\begin{array}{l}\text { No } \\
\text { amplification }\end{array}$ \\
\hline $\begin{array}{l}\text { Fusarium } \\
\text { avenaceum }\end{array}$ & $\begin{array}{l}\text { ISO2-125- } \\
\text { MKR }\end{array}$ & Fragaria ananassa & $\begin{array}{l}\text { Isolated from North Savo region of Finland by the University of } \\
\text { Eastern Finland }\end{array}$ & $\begin{array}{l}\text { No } \\
\text { amplification }\end{array}$ \\
\hline $\begin{array}{l}\text { Fusarium } \\
\text { proliferatum }\end{array}$ & $\begin{array}{l}\text { Tiste Koe } \\
25\end{array}$ & Fragaria ananassa & $\begin{array}{l}\text { Isolated from North Savo region of Finland by the University of } \\
\text { Eastern Finland }\end{array}$ & $\begin{array}{l}\text { No } \\
\text { amplification }\end{array}$ \\
\hline
\end{tabular}

(Dai et al. 2019a; Dai et al. 2019b; Yu et al. 2019). In contrast, the mitochondrial atp9-nad9 marker is a multicopy locus and exhibits enough sequence divergence for designing assay on species-level identification of Phytophthora. The atp9-nad9 marker is unique to genus Phytophthora but is absent in related genus Pythium, Eumycotan fungi and plants (Bilodeau et al. 2014; Miles et al. 2015; Miles et al. 2017). For these reasons, we also targeted the atp9nad9 marker for designing $P$. fragariae-specific RPA assay. Although species-level RPA assays were successfully developed in a wide range of Phytophthora taxa by using the atp9-nad9 marker (Miles et al. 2015; Rojas et al. 2017), RPA assay of this study has only been validated against a limited number of taxa due to limited resources and therefore, we strongly recommend further analysis of specificity with more taxa.

In our RPA primer screening process, we faced the challenge of background amplification that was resolved through redesigning reverse primers from adjacent locations. RPA primers depend on enzymes and proteins for 
Table 3 Field validation results

\begin{tabular}{|c|c|c|c|c|c|}
\hline $\begin{array}{l}\text { Rootlet sample } \\
\text { No. }\end{array}$ & $\begin{array}{l}\text { P. fragariae-specific RPA } \\
\text { assay of this study }\end{array}$ & $\begin{array}{l}\text { P. fragariae-specific SYBR } \\
\text { Green PCR assay }\end{array}$ & $\begin{array}{l}\text { P. fragariae-specific } \\
\text { TaqMan PCR assay }\end{array}$ & $\begin{array}{l}\text { Sanger's } \\
\text { sequencing } \\
\text { results }\end{array}$ & Symptoms \\
\hline 98 & $\begin{array}{l}\text { Positive } \\
\text { Onset at } \sim 5 \mathrm{~min}\end{array}$ & $30.7 \mathrm{Ct}$ & $34.6 \mathrm{Ct}$ & $\begin{array}{l}100 \% \text { identical } \\
\text { to JF771842 }\end{array}$ & $\begin{array}{l}\text { Wilting, stunting and red } \\
\text { steles }\end{array}$ \\
\hline 99 & $\begin{array}{l}\text { Positive } \\
\text { Onset at } \sim 6 \mathrm{~min}\end{array}$ & $30.8 \mathrm{Ct}$ & $34.4 \mathrm{Ct}$ & $\begin{array}{l}100 \% \text { identical } \\
\text { to JF771842 }\end{array}$ & $\begin{array}{l}\text { Wilting, stunting and red } \\
\text { steles }\end{array}$ \\
\hline 101 & $\begin{array}{l}\text { Positive } \\
\text { Onset at } \sim 6 \mathrm{~min}\end{array}$ & $30.7 \mathrm{Ct}$ & $34.2 \mathrm{Ct}$ & $\begin{array}{l}100 \% \text { identical } \\
\text { to JF771842 }\end{array}$ & $\begin{array}{l}\text { Wilting, stunting and red } \\
\text { steles }\end{array}$ \\
\hline 102 & $\begin{array}{l}\text { Positive } \\
\text { Onset at } \sim 6 \mathrm{~min}\end{array}$ & $30.0 \mathrm{Ct}$ & $34.1 \mathrm{Ct}$ & $\begin{array}{l}\text { 100\% identical } \\
\text { to JF771842 }\end{array}$ & $\begin{array}{l}\text { Wilting, stunting and red } \\
\text { steles }\end{array}$ \\
\hline 105 & $\begin{array}{l}\text { Positive } \\
\text { Onset at } \sim 5 \mathrm{~min}\end{array}$ & $34.3 \mathrm{Ct}$ & $37.0 \mathrm{Ct}$ & $\begin{array}{l}100 \% \text { identical } \\
\text { to JF771842 }\end{array}$ & $\begin{array}{l}\text { Wilting, stunting and red } \\
\text { steles }\end{array}$ \\
\hline 106 & Negative & $\mathrm{No} C t$ & $\mathrm{No} C t$ & No amplification & Stunting \\
\hline 107 & $\begin{array}{l}\text { Positive } \\
\text { Onset at } \sim 7 \mathrm{~min}\end{array}$ & $34.7 \mathrm{Ct}$ & $38.3 \mathrm{Ct}$ & $\begin{array}{l}\text { 100\% identical } \\
\text { to JF771842 }\end{array}$ & $\begin{array}{l}\text { Wilting, stunting and red } \\
\text { steles }\end{array}$ \\
\hline $\begin{array}{l}108 \text { (co- } \\
\text { infected } \\
\text { sample) }\end{array}$ & $\begin{array}{l}\text { Positive } \\
\text { Onset at } \sim 6 \mathrm{~min}\end{array}$ & $33.1 \mathrm{Ct}$ & $37.2 \mathrm{Ct}$ & $\begin{array}{l}100 \% \text { identical } \\
\text { to JF771842 }\end{array}$ & $\begin{array}{l}\text { Wilting, stunting, red steles, } \\
\text { and typical crown rot }\end{array}$ \\
\hline 109 & Negative & $\mathrm{No} C t$ & $\mathrm{No} C t$ & No amplification & Stunting \\
\hline 110 & Negative & $\mathrm{No} C t$ & $\mathrm{No} C t$ & No amplification & Stunting \\
\hline 111 & $\begin{array}{l}\text { Positive } \\
\text { Onset at } \sim 7 \mathrm{~min}\end{array}$ & $32.5 \mathrm{Ct}$ & $36.5 \mathrm{Ct}$ & $\begin{array}{l}100 \% \text { identical } \\
\text { to JF771842 }\end{array}$ & $\begin{array}{l}\text { Wilting, stunting and red } \\
\text { steles }\end{array}$ \\
\hline 112 & Negative & $\mathrm{No} C t$ & $\mathrm{No} C t$ & No amplification & Apparently healthy \\
\hline 114 & Negative & $\mathrm{No} C t$ & $\mathrm{No} C t$ & No amplification & Wilting and typical crown rot \\
\hline 117 & $\begin{array}{l}\text { Positive } \\
\text { Onset at } \sim 6 \mathrm{~min}\end{array}$ & $29.2 \mathrm{Ct}$ & $32.7 \mathrm{Ct}$ & $\begin{array}{l}100 \% \text { identical } \\
\text { to JF771842 }\end{array}$ & Wilting and red steles \\
\hline 118 & Negative & $\mathrm{No} C t$ & $\mathrm{No} C t$ & No amplification & Wilting and typical crown rot \\
\hline 119 & Negative & $\mathrm{No} C t$ & No Ct & No amplification & Wilting \\
\hline 120 & Negative & $\mathrm{No} C t$ & $\mathrm{No} C t$ & No amplification & Wilting and typical crown rot \\
\hline 121 & Negative & $\mathrm{No} C t$ & $\mathrm{No} C t$ & No amplification & Wilting and typical crown rot \\
\hline 122 & Negative & $\mathrm{No} C t$ & $\mathrm{No} C t$ & No amplification & Stunting \\
\hline 123 & $\begin{array}{l}\text { Positive } \\
\text { Onset at } \sim 8 \mathrm{~min}\end{array}$ & $38.5 \mathrm{Ct}$ & $40.6 \mathrm{Ct}$ & $\begin{array}{l}100 \% \text { identical } \\
\text { to JF771842 }\end{array}$ & $\begin{array}{l}\text { Minor wilting only (no red } \\
\text { steles) }\end{array}$ \\
\hline 125 & Negative & $\mathrm{No} C t$ & $\mathrm{No} C t$ & No amplification & Apparently healthy \\
\hline 127 & Negative & $\mathrm{No} C t$ & $\mathrm{No} C t$ & No amplification & Apparently healthy \\
\hline
\end{tabular}

their binding with template and limited knowledge is available about the phenomena which makes some RPA primers overly reactive and some primers non-reactive. Moreover, in our RPA assay, the TwistAmp exo probe was designed with ROX as fluorophore and BHQ2 as quencher, and we observed a slight rise in baseline fluorescence upon addition of macerate. The fluorescence signal rise wasn't observed upon DNA addition. To combat the problem, we reduced the probe concentration from the recommended volume of $0.6 \mu \mathrm{L}$ per reaction to

Table 4 Soil results from baiting units

\begin{tabular}{llccccc}
\hline Baiting units & $\begin{array}{l}\text { Positive units } \\
\text { day } 7\end{array}$ & $\begin{array}{l}\text { Positive units } \\
\text { day } 10\end{array}$ & $\begin{array}{l}\text { Positive units } \\
\text { day } 14\end{array}$ & $\begin{array}{l}\text { Positive units } \\
\text { day } 21\end{array}$ & $\begin{array}{l}\text { Positive units } \\
\text { day } 35\end{array}$ & $\begin{array}{l}\text { Positive units } \\
\text { day } 49\end{array}$ \\
\hline Hemp side soil & $2 / 8$ & $2 / 8$ & $2 / 8$ & $2 / 8$ & $3 / 8$ & $3 / 8$ \\
Pea side soil & $0 / 8$ & $1 / 8$ & $1 / 8$ & $2 / 8$ & $2 / 8$ & $2 / 2$ \\
Positive control unit & $2 / 2$ & & & & $0 / 2$ \\
Negative control unit & $0 / 2$ & & & & \\
\hline
\end{tabular}


$0.5 \mu \mathrm{L}$ or sometimes $0.45 \mu \mathrm{L}$. Labelling the probe with FAM did not have the same problem with increasing fluorescence in our previous $P$. cactorum assay (Munawar et al. 2019), so we recommend labelling the TwistAmp exo probe with FAM/ BHQ1 and utilizing the optimum concertation of probe for improving the assay's sensitivity. Furthermore, a TwistAmp exo probe labelled with FAM/ BHQ1 is less expensive than the one labelled with ROX/ BHQ2.

RPA is a rapid molecular biology technology for amplifying target nucleic acid, and it has potential to expedite plant diagnostics. RPA amplifies target nucleic acid from simple macerates and thereby eliminates the need for time-consuming and problematic DNA extraction. Additionally, RPA runs for only 20-30 min. Besides time-saving aspect, RPA requires minimal laboratory settings. Being an isothermal nucleic acid amplification technology, RPA does not require sophisticated thermocycler and it can be run with simple portable incubation/ detection devices at field sites ( $\mathrm{Li}$ et al. 2019). Regarding the cost of RPA, it is comparable with the standard diagnostic method of DNA extraction followed by TaqMan PCR. The current price of RPA kit 'TwistAmp exo' for 96 samples is 340 euros, while the RPA probe 'TwistAmp exo probe (ROX/ BHQ2)' at $200 \mathrm{nmol}$ size was purchased for 450 US dollars from LGC Biosearch Technologies (United States) in 2017. The probe was enough for several RPA kits. Regarding the cost of the standard diagnostic method, DNA extraction kit 'DNeasy Plant Mini kit' (Qiagen, Germany) for 50 samples is currently sold at 207 euros, and the TaqMan reaction mix 'Luminaris Probe qPCR Master Mix' (Thermo Fisher Scientific) for around 250 reactions is currently priced at 182 euros. We acquired the TaqMan probe ( $5^{\prime}$ FAM/ZEN/ 3'IBFQ quencher) at the smallest delivery amount $(0.5$ nmol) from Integrated DNA Technologies (Belgium) at a price of 65 euros.

Regarding maceration, several reagents have been applied to prepare plant crude macerates that can be directly utilized in RPA reaction. Those reagents include TE buffer (Ahmed et al. 2018), $\mathrm{NaOH}$ (Karakkat et al. 2018; Qian et al. 2018), standard ELISA grinding buffer (Miles et al. 2015), and commercial buffers GEB (Kumar et al. 2018), GEB 2 (Miles et al. 2015; Li et al. 2017), GEB 4 (Zhang et al. 2014) and AMP1 (Kalyebi et al. 2015; Ghosh et al. 2018) from Agdia, Inc. In contrast, our investigation on standard ELISA grinding buffer revealed that no component of the buffer was essential for obtaining RPA amplification. We repeated the investigations for our previously developed RPA assay targeting P. cactorum (Munawar et al. 2019) and found the RPA assay working equally well when crown macerates were prepared with distilled water. The possibility of preparing macerate in water not only simplifies the process but also reduce cost.
Isolation of $P$. fragariae remains challenging even after several decades of pathogen discovery and there is a need for an efficient isolation method. In our project, over a hundred plates failed in the isolation of $P$. fragariae from red stele plants. Moreover, the traditional reagent utilized for $P$. fragariae isolation, Teepol $\mathrm{L}$ Detergent (Montgomerie and Kennedy 1983; George and Milholland 1986; Newton et al. 2010), showed no difference when compared with the routine laboratory disinfectant, $70 \%$ ethanol, in supressing the growth of contaminants on the Phytophthora selective agar.

Collection of appropriate strawberry plant samples is crucial in red stele diagnosis. As described by Ellis (2008), we observed the red stele disease first appeared in low or poorly drained sites of fields where plants started wilting and stunting, and the affected area progressively expanded. In most of the contaminated field, when we dug out tens of plants with early symptoms of wilting or stunting and dissected several rat-tail roots, we found some red steles. Occasionally we didn't find red stele in contaminated fields and only laboratory findings confirmed red stele disease. Similarly, we observed that within an infected field, plants in well-drained regions of the field remained healthy and even negative with the RPA assay. So, in the cases where affected sites are not present, plant samples should be preferably collected from low or poorly drained areas of fields. Besides appropriate plant sample collection, we recommend utilization of molecular assays when red steles are not obvious. In our observation, fine rootlets generate the most consistent results for molecular assays such as RPA or PCR. Major roots in an infected plant remain negative unless containing red stele. So, sample collection should focus on collecting a maximum of fine roots. Regarding sampling, another challenge is screening the plants already packed for sale or export. In such situations, a few plants should be analysed from each box, but the process is extremely laborious.

Soil testing is generally desired when a field is not under strawberry cultivation. Our results from planting indicator plants in the fields confirm that solely relying on symptoms of the indicator plants can be misleading. For instance, among the five indicator plants planted in the field A's active disease site, all the five had the disease (RPA positives), but only one of the plants exhibited the typical symptom of red stele. Although coupling indicator or bait plants with molecular assay of RPA gave better results, a negative result cannot confirm the absence of the pathogen. Field B had red stele disease a few years ago, and among the 10 randomly planted indicator plants, only one was positive with the $P$. fragariae RPA assay. The indicator plant which caught the disease might be the only one that by chance got planted in a heavily infested site of the field $\mathrm{B}$. We recommend that 
indicator plants should be planted in lower or poorly drained sites of a field and any site known for heavy damage during the previous strawberry cultivation. The indicator plants should be planted in early or late summer and well irrigated to provide the pathogen a favoring environment to infect.

Regarding the soil testing, Duncan (1976) potted field soils and their dilutions to bait $P$. fragariae with indicator plants. We found that field soil samples are often inappropriate for potting indicator plants due to their heavy texture. Moreover, preparing soil dilutions is laborious. For these reasons, we developed a simple baiting system. The baiting system coupled with the RPA assay detected $P$. fragariae in some of the soil samples but didn't turn all the soil samples positive within the traditional baiting period of five weeks. While the number of soil samples and duration of baiting are the factors to be considered, the number of years elapsed from active infection may also influence the degree of pathogen survival and reliability of the baiting system. We recommend the collection of several soil samples, especially targeting sites with a history of heavy damage and the poorly-drained ones. Moreover, keeping the experiment temperature low at around $15^{\circ} \mathrm{C}$ is crucial for $P$. fragariae infectivity. Finally, special care should be taken during field inspection and sampling to prevent humanassisted spread of Phytophthora across fields. Protective measures include changing shoes cover and washing of sample collection tools prior to moving to the next field.

\section{Conclusions}

In this study, we developed a rapid, specific, and sensitive species-specific detection assay for $P$. fragariae utilizing RPA technology and targeting the Phytophthora mitochondrial DNA intergenic marker located between atp 9 and nad 9 genes. We believe that our rapid assay can assist in halting the spread of $P$. fragariae and preventing economic losses of red stele disease of strawberry. We also developed a simpler baiting system compared to the traditional Duncan's baiting for detection of the pathogen in soil. Coupling the baiting with molecular assays such as PCR or RPA provides more reliable results.

\section{Methods}

\section{Isolation of $P$. fragariae}

Rat-tail roots were dissected with a scalpel to observe the presence of red cores. Rat-tails with red cores were further peeled and red cores were surface disinfected, dried, and placed on Phytophthora selective agar (Drenth and Sendall 2001). The Phytophthora selective agar comprised of corn meal agar (Sigma-Aldrich) supplemented with final concentration of $250 \mu \mathrm{g} / \mathrm{mL}$ for ampicillin (Sigma-Aldrich), $25 \mu \mathrm{g} / \mathrm{mL}$ for benomyl (Sigma-Aldrich), $10 \mu \mathrm{g} / \mathrm{mL}$ for pimaricin (Molekula, Germany), $10 \mu \mathrm{g} / \mathrm{mL}$ for rifampicin (Duchefa Biochemie, Netherlands) and $50 \mu \mathrm{g} / \mathrm{mL}$ for hymexazol (Alfa Aesar). Surface disinfestation of red stele plants was accomplished by incubating in either 70\% ethanol or Teepol L Detergent from Stratlab Ltd. UK. When using 70\% ethanol, infected roots were given a dip. For Teepol, infected roots were first dipped in 50\% Teepol L Detergent for $1 \mathrm{~min}$ and then dipped in three vials containing autoclaved distilled water for 5-10 min per vial. Following surface disinfestation, roots were surface dried by placing them on filter paper.

\section{Collection of atp-nad9 sequences}

$P$. fragariae isolates retrieved from different strawberry fields were grown in peptone glucose broth (Unestam 1965) supplemented with pea broth (Zentmyer and Chen 1969) for around a week at room temperature. The proportion of pea broth in the peptone glucose broth was $5-10 \%(\mathrm{v} / \mathrm{v})$. After growing $P$. fragariae isolates, hyphae were washed and dried overnight in an oven at $45^{\circ} \mathrm{C}$. DNA was extracted by E.Z.N.A. Fungal DNA Mini Kit (Omega Bio-tek, United States). Similarly, fine rootlets were collected from strawberry plants where P. fragariae was not isolated and DNA was then extracted with the DNeasy Plant Mini kit (Qiagen) as per manufacturer's recommendations.

The P. fragariae atp9-nad9 marker was amplified and Sanger sequenced as previously described (Martin and Coffey 2012; Bilodeau et al. 2014). The amplification PCR was performed using DreamTaq Green PCR Master Mix (2X) (Thermo Fisher Scientific, United States) with an annealing temperature of $57^{\circ} \mathrm{C}$. Sanger sequencing was accomplished at GATC Biotech, Germany.

\section{RPA optimization}

Primer screening for specificity included five forward primers, 21 reverse primers, and one probe. The RPA primers were obtained as standard desalted purified DNA from Integrated DNA Technologies, while the TwistAmp exo probe labelled with ROX fluorophore and BHQ2 quencher, and purified with dual HPLC was obtained from LGC Biosearch Technologies. Ready-to-use lyophilised RPA reactions 'TwistAmp exo' were obtained from TwistDx Inc. (United Kingdom). Primer screening was accomplished as per manufacturer's recommendations. For the optimum primer pair, different ratios of forward and reverse primers were further evaluated. $P$. fragariae hyphal DNA of varying concentrations was utilized as template. RPA reaction incubation and fluorescence monitoring were accomplished through T8-ISO (Axxin, Australia) or Mx3000P QPCR System (Agilent, Germany). Reaction strips were incubated at $39^{\circ} \mathrm{C}$ for 20 min with a manual agitation at the fourth minute. Results were reported as negative, positive, and intermediate. The absence of 
amplification was considered a negative result. Similarly, any amplification curve shorter or less steep than the curve of $10 \mathrm{fg}$ dilution, $P$. fragariae genomic DNA dilution spiked with healthy rootlets macerate, was considered intermediate. Intermediate results were rare, and they were always repeated with new plant samples. Regarding positive result criteria, any amplification curve equal or more in terms of height and steepness compared to the amplification curve of $10 \mathrm{fg}$ DNA was considered a positive. In the T8-ISO settings, it is also possible to set minimum values for curve amplitude (height) and gradient (steepness) as criteria for positive results. We set a minimum gradient threshold at $7.0 \mathrm{mV} / \mathrm{s}$ and a minimum amplitude at $3000 \mathrm{mV}$. We set ROX as the test channel and its LED PWM level at 30\%.

\section{SYBR green and TaqMan PCR assays}

P. fragariae-specific SYBR Green and TaqMan PCR assays described in Munawar et al. (2020) and Bilodeau et al. (2014) were utilized in this study. Those PCR assays were also designed from atp9-nad 9 marker. The $P$. fragariae SYBR Green PCR assay was done with forward primer 'Phy_Gen_SeqF4' (ACAACAAGAATTAATGAG AACTGC), reverse primer 'Phy_Frag_PCRR4' (TTTTTG TTTGAAAAGAGCTA) and LightCycler 480 SYBR Green I Master (Roche, Switzerland). The PCR program included a $10 \mathrm{~min}$ pre-denaturation at $95^{\circ} \mathrm{C}$ and 40 thermal cycles, each cycle comprising $95^{\circ} \mathrm{C}$ for $10 \mathrm{~s}, 58^{\circ} \mathrm{C}$ for $20 \mathrm{~s}$ and $67^{\circ} \mathrm{C}$ for $20 \mathrm{~s}$. The P. fragariae TaqMan PCR assay was done with forward primer 'Phy_Gen_ SeqF4', reverse primer 'Phy_Gen_SeqR8' (GGTAAAAT TTGTAATAAATATTGACT), TaqMan probe 'PfraVf nad9sp_TaqMan2' (/56-FAM/ATC TCG TAA /ZEN/
TAG ATA TAT ATG TAT ATT TAA TAC GT/ 3IABkFQ/) and Luminaris Probe qPCR Master Mix (Thermo Fisher Scientific). The PCR included a $10 \mathrm{~min}$ pre-denaturation at $95^{\circ} \mathrm{C}$ and 45 thermal cycles, each cycle comprising $95^{\circ} \mathrm{C}$ for $15 \mathrm{~s}$ followed by $57^{\circ} \mathrm{C}$ for 90 s. Each primer concentration was kept at $500 \mathrm{nM}$ while TaqMan probe was $100 \mathrm{nM}$. Template volume was kept at $1 \mu \mathrm{L}$ for the 1:10 serial dilution of hyphal DNA and $0.5 \mu \mathrm{L}$ for plant DNA.

\section{Crude maceration}

Strawberry plant roots were washed in tap water with a final rinse in autoclaved distilled water. Fine rootlets or root tips weighing between 30 and $100 \mathrm{mg}$ were collected, chopped and transferred into $2 \mathrm{~mL}$ round-bottom Eppendorf tubes for maceration with plastic pestles. Maceration was facilitated by initially adding only $100 \mu \mathrm{L}$ fluid. Following maceration, additional fluid was supplemented to prepare a final 1:10 (w/v) macerate. The macerate was vortexed and left to settle for a few minutes. Then $1 \mu \mathrm{L}$ of the supernatant was transferred to the RPA reaction.

\section{Field soil collection}

Soil samples from lower part of the field $\mathrm{C}$ were collected from around 3-5 m distances. Soil samples of volume 10-15 L were collected with a shovel from around a $25 \mathrm{~cm}$ depth. Soil samples were stored at $4{ }^{\circ} \mathrm{C}$ until the baiting experiment was conducted in the autumn of 2018. Before baiting, soil samples were mixed and then five litres of soil from each sample was moved to a corresponding baiting container.

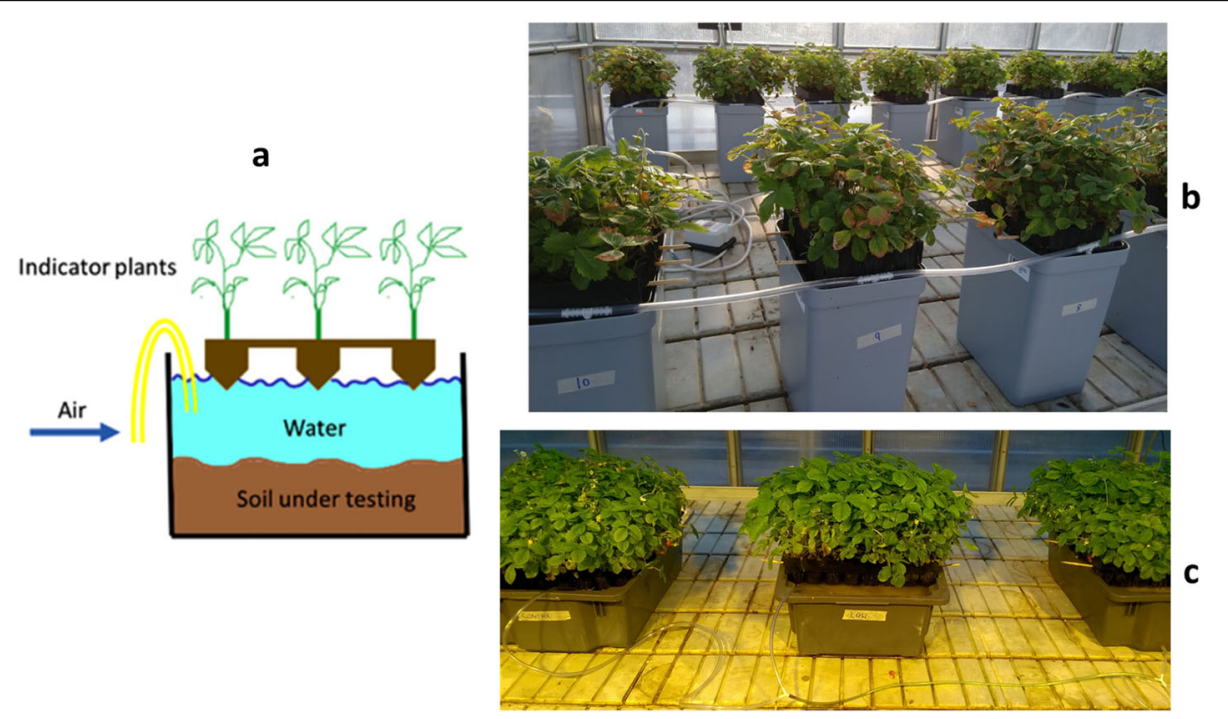

Fig. 4 Baiting unit used in this study for detection of $P$. fragariae. a Basic model of baiting unit. $\mathbf{b}, \mathbf{c}$ Images of different baiting unit setups in a greenhouse 


\section{Baiting unit}

A baiting unit comprises a simple container of 10 to 20 $\mathrm{L}$ volume. The bottom of the container is first filled with test soil and then an equal volume of distilled water is added. The container is topped with a tray of indicator plants. The tray is a plastic pot block with porous bottom, and it was sown with indicator plant Fragaria vesca var. alpina (Baron Solemacher) seeds approximately two months prior experimentations. In the baiting unit, the level of the tray was set so that only the porous bottom of the tray was touching the water layer in the unit. The water layer was also aerated through air pump and tubing. Fig. 4 presents model and images of baiting units. The experiments were conducted in autumn or early winter in a greenhouse with the temperature set at 12$18^{\circ} \mathrm{C}$. All the units were filled with distilled water every second day to maintain an adequate water level.

\section{Supplementary information}

Supplementary information accompanies this paper at https://doi.org/10. 1186/s42483-020-00069-4.

Additional file 1 Figure S1. Screenshots of Geneious alignment for the atp9-nad9 sequences of Phytophthora species provided by Miles et al. (2015). For the $P$. fragariae atp9-nad9 sequence, primers and probe binding regions are annotated.

\section{Abbreviations}

BSA: Bovine serum albumin; $C A B I$ : Centre for Agriculture and Biosciences International; DIAPOPS: Detection of immobilized amplified product in a one-phase system; ELISA: Enzyme-linked immunosorbent assay; EPPO: European and Mediterranean Plant Protection Organization; EVIRA: Elintarviketurvallisuusvirasto or Finnish Food Safety Authority; GEB: General Extract Buffer; ILVO: Institute for Agricultural, Fisheries and Food Research; ITS: Internal transcribed spacer; JKI: Julius Kühn-Institut; LUKE: Natural Resources Institute Finland; PVP: Polyvinylpyrrolidone; RPA: Recombinase polymerase amplification

\section{Acknowledgements}

Most of the laboratory and field work was accomplished during the Taut voi ei!' project funded by Euroopan maaseudun kehittämisen maatalousrahasto (European Agricultural Fund for Rural Development/ EAFR D), Pohjois-Savon ELY-Keskus. The corresponding author also received personal grants from Finnish Cultural Foundation and Olvi Foundation, Finland to finalize this manuscript.

\section{Authors' contributions}

Most of the lab work was completed by MM. Similarly, the design of the RPA assay was conceived by MM. The design of baiting unit was conceived by HK. The manuscript was written by MM, while all other co-authors have contributed in improving the manuscript. Funding was acquired by HK. All authors read and approved the final manuscript.

\section{Funding}

This work was supported by the European Agricultural Fund for Rural Development (EAFRD), Pohjois-Savon ELY-Keskus.

\section{Availability of data and materials}

Not applicable.

Ethics approval and consent to participate Not applicable.
Consent for publication

Not applicable.

\section{Competing interests}

The authors declare that they have no competing interests.

\section{Author details}

${ }^{1}$ Department of Environmental and Biological Sciences, University of Eastern Finland, 70211 Kuopio, Finland. ${ }^{2}$ United States Department of Agriculture, ARS, Salinas CA-93905, USA.

Received: 14 May 2020 Accepted: 20 August 2020

Published online: 31 August 2020

\section{References}

Ahmed FA, Larrea-Sarmiento A, Alvarez AM, Arif M. Genome-informed diagnostics for specific and rapid detection of Pectobacterium species using recombinase polymerase amplification coupled with a lateral flow device. Sci Rep. 2018;8:15972.

Amouzou-Alladaye E, Dunez J, Clerjeau M. Immunoenzymatic detection of Phytophthora fragariae in infected strawberry plants. Phytopathology. 1988; 78:1022-6.

Bilodeau GJ, Martin FN, Coffey MD, Blomquist CL. Development of a multiplex assay for genus- and species-specific detection of Phytophthora based on differences in mitochondrial gene order. Phytopathology. 2014;104:733-48.

Bonants P, Hagenaar-de Weerdt M, van Gent-Pelzer M, Lacourt I, Cooke D, Duncan J. Detection and identification of Phytophthora fragariae Hickman by the polymerase chain reaction. Eur J Plant Pathol. 1997;103:345-55.

Bonants PJM, van Gent-Pelzer MPE, Hooftman R, Cooke DEL, Guy DC, Duncan JM. A combination of baiting and different PCR formats, including measurement of real-time quantitative fluorescence, for the detection of Phytophthora fragariae in strawberry plants. Eur J Plant Pathol. 2004;110:689-702.

Camele I, Marcone C, Cristinzio G. Detection and identification of Phytophthora species in southern Italy by RFLP and sequence analysis of PCR-amplified nuclear ribosomal DNA. Eur J Plant Pathol. 2005;113:1-14.

Cooke DE, Duncan JM. Phylogenetic analysis of Phytophthora species based on ITS1 and ITS2 sequences of the ribosomal RNA gene repeat. Mycol Res. 1997; 101:667-77.

Dai T, Hu T, Yang X, Shen D, Jiao B, Tian W, Xu Y. A recombinase polymerase amplification-lateral flow dipstick assay for rapid detection of the quarantine citrus pathogen in China, Phytophthora hibernalis. PeerJ. 2019a;7:e8083.

Dai T, Yang X, Hu T, Xu Y, Zheng X, Jiao B, Shen D. Comparative evaluation of a novel recombinase polymerase amplification-lateral flow dipstick (RPA-LFD) assay, LAMP, conventional PCR, and leaf-disc baiting methods for detection of Phytophthora sojae. Front Microbiol. 2019b;10:1884.

Drenth A, Sendall B. Practical guide to detection and identification of Phytophthora. CRC for Tropical Plant Protection. Brisbane: Australian Center for International Agricultural Research (ACIAR); 2001.

Drenth A, Wagels G, Smith B, Sendall B, O'Dwyer C, Irvine G, et al. Development of a DNA-based method for detection and identification of Phytophthora species. Australas Plant Pathol. 2006:35:147-59.

Duncan JM. The use of bait plants to detect Phytophthora fragariae in soil. Trans Br Mycol Soc. 1976;66:85-9.

Duncan JM. A technique for detecting red stele (Phytophthora fragariae) infection of strawberry stocks before planting. Plant Dis. 1980;64:1023-5.

Ellis MA. Red stele root rot of strawberry. 2008. https://ohioline.osu.edu/factsheet/ plpath-fru-34. Accessed 12 Jan 2020

EPPO/CABI. Quarantine Pests for Europe. 2nd ed. Wallingford: CAB International; 1997.

EVIRA. Finnish Food Safety Authority. New plant pests in horticultural production came as a surprise in 2012. 2013. https://gd.eppo.int/reporting/article-2636. Accessed 12 Jan 2020.

George SW, Milholland RD. Growth of Phytophthora fragariae on various clarified natural media and selected antibiotics. Plant Dis. 1986;70:1100-4.

Ghosh DK, Kokane SB, Kokane AD, Warghane AJ, Motghare MR, Bhose S, et al. Development of a recombinase polymerase based isothermal amplification combined with lateral flow assay (HLB-RPA-LFA) for rapid detection of "Candidatus Liberibacter asiaticus". PLoS One. 2018;13:e0208530.

Hao W, Miles TD, Martin FN, Browne GT, Förster H, Adaskaveg JE. Temporal occurrence and niche preferences of Phytophthora spp. causing brown rot of citrus in the central valley of California. Phytopathology. 2018;108:384-91. 
loos R, Laugustin L, Schenck N, Rose S, Husson C, Frey P. Usefulness of single copy genes containing introns in Phytophthora for the development of detection tools for the regulated species $P$. ramorum and $P$. fragariae. Eur J Plant Pathol. 2006;116:171-6.

Kalyebi A, Aisu G, Ramathani I, Ogwang J, McOwen N, Russell P. Detection and identification of etiological agents (Liberibacter spp.) associated with citrus greening disease in Uganda. Uganda J Agric Sci. 2015;16:43-54.

Karakkat BB, Hockemeyer K, Franchett M, Olson M, Mullenberg C, Koch PL. Detection of root-infecting fungi on cool-season turfgrasses using loopmediated isothermal amplification and recombinase polymerase amplification. J Microbiol Methods. 2018;151:90-8.

Kumar PV, Sharma SK, Rishi N, Ghosh DK, Baranwal VK. An isothermal based recombinase polymerase amplification assay for rapid, sensitive and robust indexing of citrus yellow mosaic virus. Acta Virol. 2018;62:104-8.

Li J, Macdonald J, von Stetten F. Review: a comprehensive summary of a decade development of the recombinase polymerase amplification. Analyst. 2019; 144:31-67.

Li R, Fuchs MF, Perry KL, Mekuria T, Zhang S. Development of a fast Amplifyrp Acceler8 diagnostic assay for grapevine red blotch virus. J Plant Pathol. 2017; 99:657-62.

Maas JL. Compendium of strawberry diseases. 2nd ed. St. Paul: APS Press; 1998.

Martin FN, Abad ZG, Balci Y, Ivors K. Identification and detection of Phytophthora: reviewing our progress, identifying our needs. Plant Dis. 2012;96:1080-103.

Martin FN, Coffey MD. Mitochondrial haplotype analysis for differentiation of isolates of Phytophthora cinnamomi. Phytopathology. 2012;102:229-39.

McGrew JR. Strawberry diseases. US Government Printing Office; 1889.

Miles TD, Martin FN, Coffey MD. Development of rapid isothermal amplification assays for detection of Phytophthora spp. in plant tissue. Phytopathology. 2015;105:265-78.

Miles TD, Martin FN, Robideau GP, Bilodeau GJ, Coffey MD. Systematic development of Phytophthora species-specific mitochondrial diagnostic markers for economically important members of the genus. Plant Dis. 2017; 101:1162-70.

Mohan SB. Cross-reactivity of antiserum raised against Phytophthora fragariae with other Phytophthora species and its evaluation as a genus-detecting antiserum. Plant Pathol. 1989;38:352-63.

Montgomerie IG, Kennedy DM. An improved method of isolating Phytophthora fragariae. Trans Br Mycol Soc. 1983;80:178-83.

Munawar MA, Martin F, Toljamo A, Kokko H, Oksanen E. RPA-PCR couple: an approach to expedite plant diagnostics and overcome PCR inhibitors. BioTechniques. 2020;69(4). https://doi.org/10.2144/btn-2020-0065 .

Munawar MA, Toljamo A, Martin FN, Kokko H. Recombinase polymerase amplification assay for fast, sensitive and on-site detection of Phytophthora cactorum without DNA extraction. Eur J Hortic Sci. 2019;84:14-9.

Newton AC, Duncan JM, Augustin NH, Guy DC, Cooke DEL. Survival, distribution and genetic variability of inoculum of the strawberry red core pathogen, Phytophthora fragariae var. fragariae, in soil. Plant Pathol. 2010;59:472-9.

Niemi J, Väre M. Agriculture and food sector in Finland 2019. Helsinki: Natural resources institute Finland; 2019. http://urnfi/URN:ISBN:978-952-326-771-8 Accessed 24 July 2020.

Pohto A. Survey for Phytophthora fragariae var. fragariae in Finland. Bull OEPP. 1999;29:159-62.

Qian W, Lu Y, Meng Y, Ye Z, Wang L, Wang R, et al. Field detection of citrus huanglongbing associated with 'Candidatus Liberibacter Asiaticus' by recombinase polymerase amplification within $15 \mathrm{~min}$. J Agric Food Chem. 2018;66:5473-80

Ristaino JB, Madritch M, Trout CL, Parra G. PCR amplification of ribosomal DNA for species identification in the plant pathogen genus Phytophthora. Appl Environ Microbiol. 1998;64:948-54

Rojas JA, Miles TD, Coffey MD, Martin FN, Chilvers MI. Development and application of qPCR and RPA genus-and species-specific detection of Phytophthora sojae and P. sansomeana root rot pathogens of soybean. Plant Dis. 2017;101:1171-81.

Stammler G, Seemüller E. Specific and sensitive detection of Phytophthora fragariae var. rubi in raspberry roots by PCR amplification. J Plant Dis Prot. 1993;100:394-400.

Unestam T. Studies on the crayfish plague fungus Aphanomyces astaci I. some factors affecting growth in vitro. Physiol Plant. 1965;18:483-505.

Werres S. Enzyme-linked immunosorbent assay (ELISA) as a method for detection of Phytophthora fragariae Hickman in strawberry roots. Nachrichtenbl Dtsch Pflanzenschutzdienstes (Braunschweig, Germany) 1988 (in German).
Yu J, Shen D, Dai T, Lu X, Xu H, Dou D. Rapid and equipment-free detection of Phytophthora capsici using lateral flow strip-based recombinase polymerase amplification assay. Lett Appl Microbiol. 2019;69:64-70.

Zentmyer GA, Chen DW. Production of sporangia by Phytophthora cinnamomi in pure culture. California Avocado Society, Yearbook, vol. 53; 1969. p. 103-7.

Zhang S, Ravelonandro M, Russell P, McOwen N, Briard P, Bohannon S, et al. Rapid diagnostic detection of plum pox virus in Prunus plants by isothermal AmplifyRP ${ }^{\circledR}$ using reverse transcription-recombinase polymerase amplification. J Virol Methods. 2014;207:114-20.

\section{Ready to submit your research? Choose BMC and benefit from:}

- fast, convenient online submission

- thorough peer review by experienced researchers in your field

- rapid publication on acceptance

- support for research data, including large and complex data types

- gold Open Access which fosters wider collaboration and increased citations

- maximum visibility for your research: over $100 \mathrm{M}$ website views per year

At BMC, research is always in progress.

Learn more biomedcentral.com/submissions 